\title{
Organizational and Family Challenges Impacting the Career Decision of Women Professionals in the Rohilkhand Region, Uttar Pradesh
}

\author{
Abhinav Nath ${ }^{1}$ and Arvind Shukla ${ }^{2}$ \\ ${ }^{1}$ Assistant Professor, ${ }^{2}$ Associate Professor \\ ${ }^{1 \& 2}$ Department of Management, Invertis University, Bareilly, Uttar Pradesh, India \\ E-Mail: abhinav.n@invertis.org
}

\begin{abstract}
The present study is a work done on women professionals in the Rohilkhand region - comprising of Bareilly, Badaun, Pilibhit and Shahjahanpur districts with Bareilly being the divisional headquarter. The study is aimed at exploring and identifying those challenges that act as an impediment in the career growth of women professionals in this part of the country. For a women to be career conscious comes with various kinds of challenges and obligations in our society, and amidst that to be a career conscious lady in this part of the country which is still developing in terms of its approach and accepting changing societal trends and patterns becomes even more challenging. Therefore, majority of the ladies who are working professionals in this region takes their employment merely as a job rather than a career. They generally, succumb to family and societal norms and restrict their working domain to a mere time bound job. Also, there are various organizational and work related challenges that add up to this pressure. Those are organizational specific and vary accordingly. Therefore, the main aim of this study is to trace out by exploring and identifying all those challenges that women professionals face and present various implications of it in a rational and objective manner.
\end{abstract}

Keywords: Organizational, Family, Challenges, CareerDecisions, Rohilkhand Region, Organizational Support, Family Support, Career Advancement

\section{INTRODUCTION}

The basic nature of the research is descriptive as it describes in a systematic manner the various barriers that were perceived by women professionals in their path of career advancement. For this purpose, a questionnaire (structured) was prepared and circulated among the respondents to gather useful data. To gain better understanding and develop deeper insights into the subject, the researcher also relied on having personal interactions with the participants (as much as possible) so that their perceptions and perspectives can be understood in a more logical and rational way.

The research is carried out in the Rohilkhand region of Western Uttar Pradesh in the Bareilly division which comprises of four districts - Bareilly (divisional headquarter), Badaun, Pilibhit and Shahjahanpur.

Bareilly, being the divisional headquarter is the seventh largest city of the state and a counter magnet city, offers more job opportunities and work prospects as compared to other cities of the division.

\section{LITERATURE REVIEW}

Organization and Family are probably the two most pertinent and indispensible elements of an individual's life (Bryan, 1993). Construed by societal norms and bounded by the principle of affinity, we all want to have a family, that is totally loving and caring for us and provides us all kinds of support in our turbulent times (Athens and McIntyre, 2001). Organizations, on the other hand play an equally pivotal role in a way that we all want to work for such an organization that takes care of our needs in the best possible way. Since, majority of our needs are centered around our family, we can say that we all want to work in a progressive and renowned organization for safeguarding and protecting the needs of our families (Goliath, 2001). Organization and Family, being the two most important dimensions of our life require utmost attention from us to bring about a systematic balance between the two (Wayne, 1993). Synchronizing these important aspects of our life and bringing stability between them is an arduous task because the boundaries of Organizational work and family issues keep overlapping each other in a spontaneous manner. A major part of the research pertaining to similar issues has published its work concentrating heavily on words like work and life and achieving a balance between the two. These two words work and life have found tremendous space in the field of research and have been used from varied perspectives (Adam, 2004). Almost all major findings of varied and multifaceted researches have touched upon a single agenda and that is to bring about equity and balance between the two most important dimensions of our life. Usage and substitution of these two words i.e. Work and Life with Organization and Family is rare in nature and can be found only with those kinds of researches that focuses on studying and analyzing the career advancement patterns of employees. Within this category also, the usage is quite limited and restricted to group of studies focusing on the career development of women professionals. Within Indian context, the academic and research work is again minimal.

One of the most prominent changes that our country has witnessed in the past few decades is the increase in the number of working women professionals and their ascension to the top hierarchy of organizations. No doubt the change is positive and encouraging; it is limited in percentage and within a particular sectoral and geographical 
time frame. Women, still in India lives under considerable pressure of managing both the ends and in the process suffer a lot on personal as well as professional front (Gupta and Vijay, 2006). The arduous task of managing organizational as well as family challenges takes a heavy toll on them and as a consequence of it, women professionals in majority of the cases decides to sacrifice their career and starts taking their employment more as a job rather than a career (John, 2001). For an individual, it is very difficult to strike an appropriate balance between organizational and family responsibilities and requires effort not only from the side of the person itself but also from several other entities related to the person i.e. spouse, other members of the family, peers, superiors etc. (Parker, T and Frisch, N F, 2009). This balance is generally achieved when an individuals' right to a meaningful and respectful life, both inside and outside the work is being recognized and accepted and a basic norm for the mutual benefit of all the entities - employee, organization and the society. Generally, for women professionals to be able to concentrate on their career, an active support system at home is indispensible. The requirement becomes even more intense if the person is married and has children. With the increasing proliferation of nuclear family structure, women professionals are always at the receiving end and in majority of the cases decide to let go of their feelings and aspirations towards career enhancement and advancement.

Organizations that are sensitive to these issues related to women professionals have already started doing a lot to manage the situation and to provide better growth opportunities to their work force (Girish and Mehta, 2011) and those which are not are already at crossroads. It must be realized by organizations that synergy between organizational and family work roles is not only important for the employees but for organizations as well. To be a progressive organization, you need your employees to work with utmost efficiency which is possible only when they are provided right kind of support which they expect and anticipate from their organizations.

\section{RESEARCH METHODOLOGY}

The research is primarily descriptive in nature as it tries to explain in detail the various factors that are being perceived by women professionals as barriers to their career advancement. For the purpose of collection of data, a questionnaire was prepared that was structured in nature and contained four part. In the first part - Women Professionals were asked to mention the various barriers as perceived by them in their career advancement. In the second part, it was analyzed how family responsibilities had impacted their career. In the third and fourth part questions were related to the kind of support women professionals expect from their organizations and families. Respondents were required to evaluate the factors by way of statements with the help of a five-point likert scale that ranged from 'strongly agree' to 'strongly disagree'. For the purpose of calculation and statistical relevance, strongly agree was given 5 points and strongly disagree was given 1 point. Once the data was collected, it was tabulated with the help of Microsoft excel 2007. Various statistical methods like mean, standard deviation and ANOVA were used to validate the process of data analysis. No doubt questionnaires were distributed to the respondents, but the researcher had tried to personally gather information from the respondents by way of informal interaction/personal interviews so that the respondents are able to express their views in a better manner and thorough understanding can be developed. Differences in demographic variables were also studies and checked.

A. Respondents' Profile: From table I out of 242 women professionals, $54(22.31 \%)$ were in government schools, 62 $(25.61 \%)$ were in public sector banks, $65(26.85 \%)$ were in private sector banks, and $61(25.20 \%)$ were working in colleges of higher education.

TABLE I BACKGROUND OF THE RESPONDENTS

\begin{tabular}{|l|c|c|}
\hline \multicolumn{1}{|c|}{ Type of Respondents } & Number & Percentage \\
\hline Government Schools & 54 & 22.31 \\
\hline Public Sector Banks & 62 & 25.61 \\
\hline Private Sector Banks & 65 & 26.85 \\
\hline Colleges of Higher Education & 61 & 25.20 \\
\hline Total & 242 & 100 \\
\hline
\end{tabular}

From table II in terms of managerial hierarchy, 11.6 percent were at senior level, 51.2 percent at middle level and 37.2 percent at junior level.

TABLE II MANAGERIAL HieRARCHY OF THE RESPONDENTS

\begin{tabular}{|l|c|c|}
\hline Managerial Hierarchy & Number & Percentage \\
\hline Senior level & 28 & 11.6 \\
\hline Middle level & 124 & 51.2 \\
\hline Junior level & 90 & 37.2 \\
\hline Total & 242 & 100 \\
\hline
\end{tabular}

From Table III a large number of respondents were concentrated in the age group of 31-40 (73), followed by the age group of $41-50$ (69). 55 respondents were in the age group of 18-30 and 45 were in the age group of 51 and above.

TABLE III AgE Group Of THE RESPONDENTS

\begin{tabular}{|l|c|c|}
\hline Age Group & Number & Percentage \\
\hline $18-30$ & 55 & 22.72 \\
\hline $31-40$ & 73 & 30.16 \\
\hline $41-50$ & 69 & 28.51 \\
\hline 51 \& above & 45 & 18.59 \\
\hline Total & 242 & 100 \\
\hline
\end{tabular}

From Table IV Majority of the respondents (81.60\%) were married. Only 15.20 percent of the respondents were 
unmarried and 3.2 percent of them were single (either widow or separated).

TABLE IV MARITAL Status OF THE RESPONDENTS

\begin{tabular}{|l|c|c|}
\hline \multicolumn{1}{|c|}{ Marital Status } & Number & Percentage \\
\hline Married & 198 & 81.60 \\
\hline Unmarried & 37 & 15.20 \\
\hline Single (either widow or separated) & 07 & 3.00 \\
\hline Total & 242 & 100 \\
\hline
\end{tabular}

From table V, 88 percent of the women professionals were living in nuclear families and the remaining were living in a joint family system.

TABLE V Family StRucture Of THE RESPONDENTS

\begin{tabular}{|l|c|c|}
\hline Family structure & Number & Percentage \\
\hline Nuclear Families & 213 & 88 \\
\hline Joint Families & 29 & 12 \\
\hline Total & 242 & 100 \\
\hline
\end{tabular}

From table VI, a large percentage of respondents had either one $(40.5 \%)$ or two $(37.2 \%)$ children.

TABLE Vi Number Of ChILDREN Of THE ReSPONDENTS

\begin{tabular}{|l|c|c|}
\hline Number of children & Number & Percentage \\
\hline 1 & 98 & 40.56 \\
\hline 2 & 90 & 37.24 \\
\hline More than 2 & 17 & 7.00 \\
\hline Total & 205 & 84.80 \\
\hline
\end{tabular}

From table VII, in terms of the profession of their spouses, a significant percentage, i.e., 69.4 percent were in service, and 12.4 percent were in the business sector.

Table ViI Profession Of Spouse Of The Respondents

\begin{tabular}{|l|c|c|}
\hline Profession of Spouses & Number & Percentage \\
\hline Service & 168 & 69.40 \\
\hline Business & 30 & 12.40 \\
\hline Total & 198 & 81.80 \\
\hline
\end{tabular}

\section{DATA ANALYSIS AND MAJOR FINDINGS}

Careful analysis of data and presentation of major findings is as follows:

\section{A. Career Advancement Barriers - as Perceived by Women Professionals}

In response to this question on various barriers to career advancement, following were the responses of women professionals

1. Highly involved and committed to family responsibilities.
2. Overburdened with work.

3. Lack of time for enhancing skills .

4. No proper guidance about career advancement.

5. Absence of self-motivation.

6. Gender related issues.

7. Health issues.

Perception of women professionals towards all these factors were then studied and analyzed thoroughly. These factors have a direct bearing on the career advancement prospects of women professionals. Out of all these factors, high involvement and commitment to family responsibilities was perceived by majority of them as the most important barrier to their career advancement. Almost 70 percent of the respondents agreed that they are highly involved and committed to family responsibilities because of which their focus on career has taken a back seat. Majority of the respondents agreed to the fact that for them it is merely a job, a source of earning income and a place to have a change from there busy and hectic family life. Things like career planning and career advancement are not in their purview. Having said that, there are other women professionals as well who were thoroughly career conscious and continuously working hard to strike a balance between their organizational and family life. Since, majority of them have accepted to the fact their commitment to family responsibilities is the biggest impediment to career advancement, one of the resulting effect then is overburden of work which is obvious. Managing the challenging demands of work and fulfilling even the smallest expectation of your family does take a very heavy toll on your body and that is what has clearly been the case with majority of the respondents.

This act of managing both the ends does have certain repercussions and resulting consequences like - lack of time for self-development, which is clearly the case with majority of the respondents (primarily those who were from the banking and education industry). They agreed to the fact that there are certain skills like IT or technical skills, doing research work and working on statistical software (in the case of faculty members) case writing skills, developing professional relations and networking which they partially or completely lack. Adding to this is the fact that when you are overburdened and physically exhausted, your selfmotivation also starts declining and health deteriorates. You become susceptible and prone to mental and physical illness and several health issues crop up.

Under such circumstances, what remains necessary is mere survival and nothing else. Another thing which has been highlighted by the respondents is that proper guidance on career development and issues like managing organizational and work life at work place is very important.

Had there been better opportunities of career guidance available at work place, things would have been a little different (specified and mentioned by majority of them). During tough times and under challenging conditions, 
everyone needs a guide/mentor - someone who can guide them in their career path, one who can understand them and appreciate their efforts, one who can continuously motivate themselves to evolve into a better professional and counsel them in managing organizational and family challenges. Absence of proper guidance/mentoring was something majority of them agreed to.
Finally, significant percentage of the respondents agreed that one of the barriers in their career advancement process is gender. By this, they does not mean that male employees enjoy some special benefits in the organization, rather it is the work load of women professionals of managing both organizational and family demands, that places male employees in a better position to handle more challenging and rigorous work opportunities.

TABle ViII Career Advancement Barriers As Perceived By Women Professionals

\begin{tabular}{|l|c|c|c|c|c|c|c|}
\hline \multicolumn{1}{|c|}{ Barriers } & $\begin{array}{c}\text { Strongly } \\
\text { Agree (5) }\end{array}$ & $\begin{array}{c}\text { Agree } \\
\mathbf{( 4 )}\end{array}$ & $\begin{array}{c}\text { Agree to some } \\
\text { extent (3) }\end{array}$ & $\begin{array}{c}\text { Disagree } \\
\text { (2) }\end{array}$ & $\begin{array}{c}\text { Strongly } \\
\text { Disagree (1) }\end{array}$ & Mean & $\begin{array}{c}\text { Standard } \\
\text { Deviation }\end{array}$ \\
\hline Overburdened with work & 64 & 118 & 36 & 20 & 3 & 3.77 & 0.97 \\
\hline $\begin{array}{l}\text { Highly involved and committed to } \\
\text { family responsibilities. }\end{array}$ & 74 & 130 & 30 & 6 & 2 & 3.83 & 0.81 \\
\hline Gender Issues & 42 & 112 & 48 & 32 & 8 & 3.63 & 0.95 \\
\hline Lack of time for skill enhancement & 22 & 58 & 62 & 78 & 22 & 2.95 & 1.08 \\
\hline Absence of self-motivation & 40 & 106 & 34 & 46 & 16 & 2.97 & 1.10 \\
\hline Health issues & 24 & 74 & 82 & 26 & 36 & 2.91 & 1.02 \\
\hline Lack of proper guidance at work place & 26 & 94 & 50 & 44 & 28 & 2.98 & 0.97 \\
\hline
\end{tabular}

\section{B. Effect of Family Responsibilities on Career Advancement of Women Professionals}

Since, commitment to family responsibilities came out to be the most dominant barrier in the career advancement prospect of women professionals, the researcher sought to assess the effect of family responsibilities on women professionals' career decisions and in what ways it has impacted them. This was done through an analysis of their perceptions towards various family responsibilities. They were provided five different statements exclusively pertaining to different kinds effects of family responsibilities and their views were sought as to how it has impacted them. The researcher also tried to understand how these family responsibilities hinder with their organizational roles and in what ways they are affected while at work and performing their roles and responsibilities. A significant percentage $(70 \%)$ of the women professional agreed to the fact that it is expected from females to complete all the household work and responsibilities before going to work. This expectation creates a certain kind of mental pressure on women professionals and by the time they reach their work place they are mentally and physically drained out to a certain extent and the only task that remains in front of them is to complete all the organizational duties somehow. Matters related to career advancement and career progression seems out of proportion under such circumstances.

TABLE IX EFFECT Of FAMILy ResponsibILITIES On CAREER AdVANCEMENT OF WOMEN PROFESSIONALS

\begin{tabular}{|c|c|c|c|c|c|c|c|}
\hline Barriers & $\begin{array}{l}\text { Strongly } \\
\text { Agree (5) }\end{array}$ & $\begin{array}{l}\text { Agree } \\
\text { (4) }\end{array}$ & $\begin{array}{c}\text { Agree to } \\
\text { some extent } \\
(3)\end{array}$ & $\begin{array}{l}\text { Disagree } \\
\quad(2)\end{array}$ & $\begin{array}{c}\text { Strongly } \\
\text { Disagree (1) }\end{array}$ & Mean & $\begin{array}{l}\text { Standard } \\
\text { Deviation }\end{array}$ \\
\hline $\begin{array}{l}\text { Family responsibilities don't allow you to } \\
\text { perform well at work and you are expected to } \\
\text { finish all household duties before going to work. }\end{array}$ & 92 & 112 & 26 & 12 & 0 & 4.26 & 0.85 \\
\hline $\begin{array}{l}\text { You are partially drained out (mentally and } \\
\text { physically) by the time you reach office. }\end{array}$ & 70 & 116 & 10 & 18 & 6 & 4.49 & 0.66 \\
\hline $\begin{array}{l}\text { Putting career ahead of family will not be } \\
\text { accepted at all(to the family) }\end{array}$ & 36 & 110 & 66 & 10 & 26 & 4.28 & 0.71 \\
\hline $\begin{array}{l}\text { Responsibilities related to children cannot be } \\
\text { compromised for the sake of career advancement. }\end{array}$ & 90 & 82 & 42 & 24 & 4 & 4.09 & 0.88 \\
\hline $\begin{array}{l}\text { Some family tensions and family issues keeps you } \\
\text { worry at the work place and you are not able to } \\
\text { utilize your full potential. }\end{array}$ & 88 & 40 & 86 & 18 & 10 & 3.84 & 1.23 \\
\hline
\end{tabular}

Whether applicable in their case or not, but majority of the women professionals have also accepted that for a women professional it is not all possible to put career ahead than family. And if you are married, than it's quite a distant reality. Also, responsibilities of raising children and looking after their development cannot be neglected at any cost, and career tradeoffs are expected to be made under such circumstances. Being a mother is probably the biggest accomplishment for any woman and that feeling can never be substituted by anything (including matters related to career).

Lastly, majority of the respondents have also agreed that some or the other family tension or issue always keeps them at bay while they are at work and hinders with their overall productivity at work. 
C. Organizational Support Women Professionals Seek to Manage their Work-Family Challenges

In this section of the research, the researcher tried to analyze the type of support women professionals seek from their organizations to manage their work and family related challenges and also to focus on their career advancement. When the respondents were asked to mention the kind of support they anticipate from their employers, following (mentioned in table) responses were put forward. Majority of the respondents said that one of the problems that they face is regarding rigidity in the system with respect to flexibility in working hours and working style. Respondents agreed that they need some kind of flexibility in the form of short leaves (for coming a bit late or going early), not staying for too long outside working hours, at times bringing your child at work (response given by school teachers and that too children above 6 years of age and only under special circumstances when there is no one at home to look after them). In context to this, majority of the respondents also agreed that women professionals who are working mothers with infants and toddlers need additional support and flexibility in their work schedule. One noteworthy thing that came out as a finding was respondents from private schools and colleges of higher education (private) said that their organization did not have proper leave system with respect to maternity leaves. Some organizations do give maternity leaves ranging from 30-90 days with loss of pay, some give 2-3 months maternity leave with pay while others totally deny it. The system is totally unorganized. It has also been reported by some of them that in the private sector if you have good connections with your reporting boss and the top management than you can avail such benefits otherwise it is very difficult to ask for such things. Another important thing that was accepted by majority of the respondents is the support of management, peers and subordinates which is indispensible for working women professionals. Apart from this, proper guidance and giving best possible advice in matters related to career development and progression is also very important. They also emphasized that it is imperative for organizations to keep organizing some motivational sessions, leisure trips and work-life balance workshops that can help the women professionals remove monotony from their work schedule and bring equity and stability with their organizational and work life. And finally, proper system of leaves came out as the last major support women professionals seek from their organizations. Majority of the respondents who were in the private sector craved for having more number of leaves as several organizations were not having proper leave structure and were not giving leaves on major festivals as well. That prohibited the women professionals to spend quality time with their families and if they do remain on leave than their salaries are being cut.

TABle X Organizational Support Women Professionals SeEk To Manage Their Work-Family Challenges

\begin{tabular}{|l|c|c|c|c|c|c|c|}
\hline \multicolumn{1}{|c|}{ Barriers } & $\begin{array}{c}\text { Strongly } \\
\text { Agree (5) }\end{array}$ & $\begin{array}{c}\text { Agree } \\
\text { (4) }\end{array}$ & $\begin{array}{c}\text { Agree to some } \\
\text { extent (3) }\end{array}$ & $\begin{array}{c}\text { Disagree } \\
\text { (2) }\end{array}$ & $\begin{array}{c}\text { Strongly } \\
\text { Disagree (1) }\end{array}$ & Mean & $\begin{array}{c}\text { Standard } \\
\text { Deviation }\end{array}$ \\
\hline Need some amount of flexibility in working. & 96 & 84 & 42 & 18 & 2 & 4.02 & 0.97 \\
\hline $\begin{array}{l}\text { Additional flexibility for those who have infant } \\
\text { babies and toddlers. }\end{array}$ & 110 & 78 & 30 & 24 & 0 & 3.96 & 0.81 \\
\hline $\begin{array}{l}\text { Proper guidance and support of management } \\
\text { for career progression }\end{array}$ & 62 & 112 & 48 & 20 & 0 & 3.44 & 1.09 \\
\hline Support of colleagues, peers and subordinates. & 94 & 108 & 36 & 4 & 0 & 4.00 & 0.75 \\
\hline $\begin{array}{l}\text { Work life balance workshops and some stress } \\
\text { buster activities. }\end{array}$ & 32 & 182 & 26 & 02 & 0 & 3.98 & 0.83 \\
\hline Proper system of leaves. & 122 & 110 & 10 & 0 & 0 & 4.46 & 0.51 \\
\hline
\end{tabular}

D. Family Support Women Professionals Seek for Career Advancement

Managing work and life is a herculean task. Women professionals do seek an active support from their family members to help them in managing both the fronts. Amongst the various kinds of support that women professionals expect from their family members, the foremost came out to be the adjustments that they expect their family members/spouse should make in their needs and their schedules to accommodate the work priorities and work commitments of women professionals. No doubt, India has made tremendous advancements in almost every field and women are contributing and shining in almost every sector, still in this part of the country, despite all the societal developments and advancements, this entire concept of working ladies is not readily accepted and has several kinds of societal disapprovals. Working women professionals are being construed as the one not fully devoted to family, shying away from her responsibilities and the one who gives more importance to personal needs rather than family needs. Therefore, another support that women professionals do expect from their families is that their work must have complete approval from them and must not be treated in a bad manner. Acknowledgement of their effort and support in household activities became another set of expectations. In some families, keeping maid is also not a common practice and such respondents desperately wanted such kind of thing to stop with immediate effect. And lastly, but by no means the least, respondents expect that family members must understand their work commitments and priorities under circumstances when they are late from work or working on a holiday.

Their spouse/family members must act as a motivating force for them and help them or guide in their path of career development, so that they also start feeling that their families/spouse are truly a pillar of support for them. 
TABle Xi Family SupPort Women Professionals Seek For Career AdVANCEMENT

\begin{tabular}{|c|c|c|c|c|c|c|c|}
\hline Barriers & $\begin{array}{l}\text { Strongly } \\
\text { Agree (5) }\end{array}$ & $\begin{array}{l}\text { Agree } \\
\text { (4) }\end{array}$ & $\begin{array}{c}\text { Agree to some } \\
\text { extent (3) }\end{array}$ & $\begin{array}{c}\text { Disagree } \\
(2)\end{array}$ & $\begin{array}{c}\text { Strongly } \\
\text { Disagree (1) }\end{array}$ & Mean & $\begin{array}{l}\text { Standard } \\
\text { Deviation }\end{array}$ \\
\hline $\begin{array}{l}\text { Family members/Spouse should adjust their } \\
\text { needs to a certain extent }\end{array}$ & 46 & 54 & 42 & 48 & 52 & 3.02 & 0.97 \\
\hline $\begin{array}{l}\text { Doing a job must not be considered } \\
\text { bad/stigma. }\end{array}$ & 90 & 78 & 30 & 44 & 0 & 3.26 & 0.71 \\
\hline $\begin{array}{l}\text { Family must appreciate and acknowledge } \\
\text { our efforts. }\end{array}$ & 62 & 112 & 48 & 20 & 0 & 3.44 & 1.09 \\
\hline Support in household activities. & 54 & 66 & 36 & 44 & 42 & 3.62 & 0.77 \\
\hline $\begin{array}{l}\text { At times we are late too reach home, family } \\
\text { must understand our work commitments } \\
\text { under such circumstances. }\end{array}$ & 62 & 60 & 8 & 72 & 3 & 3.18 & 0.71 \\
\hline $\begin{array}{l}\text { Family members/Spouse should help us and } \\
\text { guide us by motivating to do better in our } \\
\text { career. }\end{array}$ & 94 & 74 & 50 & 24 & 0 & 4.46 & 0.59 \\
\hline
\end{tabular}

\section{ANOVA RESULTS AND ITS INTERPRETATION}

To get a better understanding and the holistic picture of the responses given by women professionals, various demographic factors like age, family structure, marital status, managerial level were analyzed through ANOVA and their findings have been presented.

\section{A. Age}

In context to the age of the respondents, the perception of women professionals to the question of most significant barrier in their career advancement - that came out to be high involvement with family responsibilities varied across different categories and age brackets. Women professionals in the age group of 18-30 (mean score 2.66) and 31-40 (mean sore 2.73) experienced the effect of this involvement more as compared to the women professionals in the age group of 41-50 and 51 and above.

The possible explanation to this difference is the fat that age group of 18-30 is that age group in which a woman starts working and also gets married. So, in the initial years of her married life, it is obvious on her part to feel that extra pressure of managing her organizational life and work life. In continuance with this, this age bracket along with the age bracket of 31-40 is that zone where after marriage a woman gets into the most important phase of her life that is motherhood and yet again there is continuous pressure on her to manage work, family and simultaneously look after the development of her children. Respondents in the age group of 41-50 and 51 above have managed to cross this stage.

They do accept the fact that involvement and commitment to family responsibilities is an important barriers in the career advancement path of any women professional but the impact of it is not that much on them at this stage of life because now they have well settled children, stable family and in majority of the cases no responsibility of looking after their in laws or other dependents. There was a marked difference in standard deviation value $(\mathrm{SD}=1.12)$ between respondents in the age group of $41-50$ and $51 \&$ above to that of respondents in the age bracket of 18-30 and 31-40.

\section{B. Marital Status}

As far as marital status is concerned, the impact of family responsibilities seemed more on married women professionals as compared to unmarried ones. While both single (mean score $=4.13$ ) and married respondents (mean score $=3.89$ ) agreed to the fact that commitment and involvement to/with family responsibilities does have a significant impact on the career advancement prospects of women professionals, the unmarried ones (mean score = 3.07) agreed less on this. Another difference was also observed in the preference of women professionals regarding flexibility of work. Married ones (3.33), single (3.19) and unmarried ones (2.89) reflects that married women professionals need more amount of work flexibility as compared to other categories of respondents.

\section{Family Structure}

With respect to family structure, majority of the respondents were living in nuclear families (88 percent) as compared to joint families (12 percent). The ANOVA results however, showed no marked difference between their acceptance to the fact that family responsibilities hindered with their career advancement prospects. Responsibility of children and its impact on their career was perceived differently. Respondents living in joint families (mean score $=4.06$ ) agreed slightly less on this as compared to the ones living in nuclear families (mean score $=3.83$ ).

This clearly indicates that living in joint families helps women professionals in raising their children and fulfilling their responsibility in a much better way as compared to living in nuclear families. In terms of making career tradeoffs both categories of respondents - nuclear and joint families showed no marked difference.

And similar with the case of flexibility in work, both nuclear family respondents - mean score (3.77) and joint family respondents - mean score (3.81) showed not much variation. While respondents from joint families have their own set of reasons for making tradeoffs like - family disapproval, societal pressures, and spouse will not agree etc, respondents from nuclear families have to look after everything related to family. 


\section{Managerial Level}

In terms of managerial hierarchy (or hierarchy within their organization because in the case of teachers there is no managerial level, but seniority level or Assistant, Associate or Professor level), the respondents at junior (mean score $=$ 4.11) and middle level (mean score $=4.26$ ) experienced the impact of family responsibilities and overburden of work more than those at senior level (mean score $=2.79$ ). Similarly, in terms of organizational support women professionals seek - junior level (mean score $=3.57$ ) and middle level respondents (mean score $=3.42$ ) were quite at par as compared to the senior level (mean score $=2.74$ ). With respect to the statement that putting career ahead of family leads to family disapproval, all the three hierarchies showed no marked difference and accepted that it is very difficult for a working professional to get family approval to concentrate more on career rather than family.

\section{CONCLUSION}

It is a reality that job scenario in India is changing at a fast pace. We are now finding increased proliferation of female employees at top positions of the company than ever before. Having said that, we must also accept that such trends are prevalent in significant percentage in metropolitan cities and across top Indian and multinational companies. There are still some parts in our country where these trends are yet to witnessed and experienced. The research that has been conducted on the above mentioned topic highlights the problems of women professionals living in the Rohilkhand region of Western Uttar Pradesh. The findings of the study provides sufficient amount of impetus for researchers to further work upon related themes and topics and present their findings. The situation that has been witnessed by the researcher during the course of the study in Western Uttar Pradesh gives a clear cut picture that majority of the working women professionals living in this part of the country make career tradeoffs owing to high involvement and commitment to family responsibilities. Along with this, there are certain other factors also like responsibility of children - nurturing and caring them in the best possible manner for their overall holistic development, family pressure and pressure of conforming to various societal norms etc. These were those fundamental factors that were construed by the women professionals acting as barriers to their prospects of career advancement. In continuance to this, the women respondents have also mentioned several other effects also that had a significant bearing of their organizational work and family life.

\section{REFERENCES}

[1] Adam, P (2004). Antecedents for organizational work and family life balance: The impact of various organizational-family challenges on career. Journal of Interpersonal behavior, 30(2), 234-256.

[2] Arihant, P (2017). Antecedents of Work-Life Determinants - Study of IT Professionals in Karnataka. Journal of Engineering and Science, 23(2), 121-127.

[3] Athens, T \& McIntyre, E (2001). Expectation of Women Professionals from their Employer and Family. Inter-science Journal, 67(3), 430-435.

[4] Buddhapriya, S (2009). Work-Family Challenges and its impact on Career Decisions - A study of Indian Women Professionals. Vikalpa, 31(1), 32-45

[5] Bryan, J (1993). Organizational Initiatives linking to career advancement: Interdependent study on women professionals in Latin America. Journal of Disciplinary Studies, 25(5), 803-810.

[6] Goliath, M (2001). Impact of various work and family related factors on individual performance, Journal of Behavioral Studies, 3, 117-121

[7] Girish, A \& Mehta, P (2011). Linking work-life balance practices and assessing its effect on individual performance. Human Resource Management, 17(1), 19-22

[8] Gupta, K \& Vijav, T.N (2006) Organizational Work-Family Life Integration. Publishing India group, 11(2), 23-28

[9] John, A (2001). Balancing multiple roles: Study of working women in middle schools of Europe. Deusch bright Publications, 4(3), 21-25.

[10] Parker, T \& Frisch, N.F (2009). Perception of Women Professionals regarding various barriers to career advancement. Palgrave Macmillan, 2008.

[11] Wayne, R (1993). Antecedents to Work-Life Balance: Individual's Perspective. Journal of Behavioral Studies, 11(2), 23-29.

[12] Saha, A (2017). Work-life Balance Strategies of Public Sector Employees in Odissa. Journal of Independent Studies, 13(4), 21-29. 